\title{
TEKNOLOGI MOTION-BASED TRACKING UNTUK PENGEMBANGAN APLIKASI KEAMANAN
}

\author{
Mira Orisa $^{\# 1}$, Karina Auliasari" ${ }^{* 2}$, Rofila El Maghfiroh ${ }^{\# 3}$ \\ "Tenik Informatika S1,Institut Teknologi Nasional Malang \\ Jalan Raya Karanglo Km 2 Malang \\ ${ }^{1}$ mir4 orisa@yahoo.co.id \\ ${ }^{3}$ rofila.elma@gmail.com \\ * Tenik Informatika S1,Institut Teknologi Nasional Malang \\ Jalan Raya Karanglo Km 2 Malang \\ ${ }^{2}$ karina.auliasari86@gmail.com
}

\begin{abstract}
The surveillance camera system is widely used by the public. The surveillance camera system used is usually a CCTV camera. In general, CCTV cameras can only record video only. Monitoring or monitoring security by CCTV cameras can only be effective if there are operators who view the recordings directly on a monitor. Actually the surveillance camera system can be programmed to give a warning sign to the user. The surveillance camera used in this study is the camera Ip.Ip camera is a programmable camera to provide a notification to the user. By applying motion-based tracking technology to the surveillance camera system can detect movement. Kalman filter is one of motion-based tracking method. Kalman filters can predict the movement recorded by the camera ip. The results of this study suggest that the surveillance camera system can provide notification messages to users through android devices when surveillance cameras record the movement of human objects.
\end{abstract}

Keywords - Android, Ip kamera, Kalman filter, Motion-based, Tracking.

\section{Pendahuluan}

Berdasarkan hasil statistik kriminal pada tahun 2014 menunjukkan bahwa pada kelompok kejahatan terhadap hak milik/barang selama periode 2011 hingga 2013 masih di dominasi jenis kejahatan pencurian. Peristiwa kejahatan yang terjadi selama periode tahun 2005-2011 pada setiap provinsi secara umum mempunyai pola yang hampir serupa dengan pola secara nasional. Kejadian kejahatan yang paling menonjol pada masing-masing provinsi selama periode tersebut berturut-turut adalah kejahatan pencurian, penganiayaan dan perampokan. Cakupan kejadian pencurian untuk keseluruhan provinsi selama tahun 2005 berada pada kisaran 17,4-68,2 persen. Cakupan kejadian tersebut pada tahun 2008 menurun menjadi sebesar 9,3-75,9 persen dan pada tahun 2011 meningkat kembali menjadi sebesar 7,8-74,5 persen[1].

Pada sebagian kasus pencurian terjadi pada tokotoko yang menggunakan kamera CCTV. Pemasangan kamera CCTV masih kurang cukup untuk mengamankan kondisi toko, hal ini dikarenakan hasil rekaman dari kamera harus tetap dimonitor oleh pihak toko yang membuat kinerja pengamanan kurang efektif. Pemasangan kamera perlu diimbangi dengan adanya aplikasi yang secara otomatis dapat memonitor objek dan memberikan peringatan kepada pemilik ataupun karyawan toko.

Penerapan Teknologi motion-based tracking pada sistem kamera pengawas dapat meningkatkan keamanan lingkungan sekitar. Salah satu metode yang digunakan untuk motion-based tracking adalah kalman filter. Seperti pada penelitian yang dilakukan oleh Diana dan Mukhlish dalam penelitiannya yang berjudul sistem deteksi objek bergerak dengan menggunakan teknik ROI dan kalman filter. Pada penelitian tersebut kalman filter digunakan untuk memprediksi gerakan objek yang terekam dalam sebuah video.Sehingga sistem akan dapat membedakan mana objek bergerak mana objek yang diam dengan memberikan sebuah bounding box pada objek yang bergerak[2].

Penelitian yang dilakukan oleh Patel dan Datshak juga tentang motion base tracking menggunakan kalman filter. Pada penelitian ini menunjukkan bahwa kalman filter dapat melacak setiap objek tunggal pada video baik di dalam ruangan maupun di luar ruangan menggunakan kamera statis dengan kondisi latar belakang moderate ataupun kompleks[3].

Kalman filter juga dapat diterapkan untuk mendeteksi beberapa objek bergerak(Multiple object 
tracking) seperti penelitian yang dilakukan oleh Jeong dkk.Jeong dkk menerapkan kalman filter untuk mendeteksi beberapa objek bergerak.Hasil penelitiannya pada kasus kawanan burung dimana pada frame ke 50 terlihat ada dua burung yang saling bergabung(marge).Pada kasus kedua adalah merekam orang yang sedang berjalan di sebuah koridor dimana terlihat pada frame adanya orang yang berlalu lalang, ada yang muncul dan lenyap darisorotan kamera, dan juga terekam ada dua orang yang berdekatan. Permaslahan seperti adanya dua objek yang bergabung atau berdekatan atau adanya objek yang muncul ataupun lenyap dari sorotan kamera dapat diatasi dengan kalman filter. Kalman filter dapat mengenali objek tersebut sebagai dua objek yang terpisah[4].

Agar sistem dapat secara otomatis memberikan peringatan kepada pengguna maka sistem dapat dilengkapi dengan sistem notifikasi.Seperti penelitian yang dilakukan oleh Antonius dkk dimana mereka membangun sebuah sistem kamera keamanan yang mendeteksi gerakan. Sistem dapat mendeteksi gerakan dengan metode adaptive motion detection algorithm. Jika sistem mendeteksi gerakan maka pengguna akan mendapatkan sebuah notifikasi di perangkat android mereka.[5]

Pada penelitian ini akan membangun sistem kamera pengawas yang akan mendeteksi gerakan pada setiap frame-frame pada rekaman video secara live. Jika ada terdeteksi pergerakan yang diidentifikasi sebagai pergerakan manusia maka sistem akan mengirimkan notifikasi ke pengguna melalui perangkat android pengguna

\section{- Tinjauan Pustaka}

\section{A. Metode Kalman Filter}

Kalman filter disebut juga sebagai persamaan matematis prediktor-korektor. Dalam proses kalman filter terjadi dua proses yaitu proses prediksi dan proses koreksi [6]. Korelasi antara kedua proses tersebut bisa dilihat pada Gambar 1.

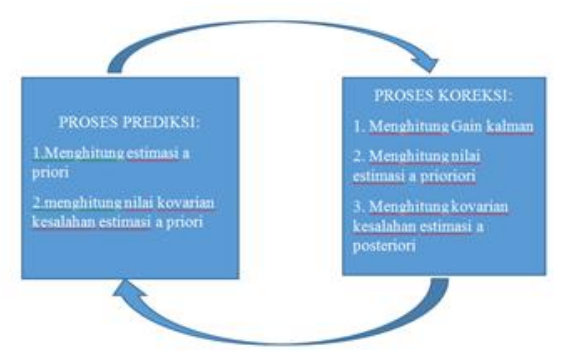

Gambar 1. Korelasi antar persamaan prediksikoreksi

\section{B. Proses Prediksi}

Proses prediksi yaitu memperkirakan kondisi yang akan datang berdasarkan kondisi lalu. Persamaan matematisnya disebut dengan persamaan prediktor atau persamaan time update.Dalam persamaan time update akan dihitung estimasi a priori dan menghitung nilai kovarian kesalahan estimasi a priori. Perhitungan estimasi apriorinya sebagai berikut[6]:

$$
\hat{x}_{k}^{-}=\hat{A} \hat{x}_{k-1}+B u_{k}
$$

Sedangkan persamaan kovarian kesalahan estimasi a priori adalah[6]:

$$
P_{k}^{-}=A P_{k-1} A^{T}+Q
$$

Dimana:

$$
\begin{aligned}
& x_{k}^{-} \text {adalah estimasi a priori saat } t_{k} \\
& x_{k-1} \quad \text { adalah estimasi a posteriori saat } t_{k-1} \\
& u_{k-1} \quad \text { adalah vector masukan saat } t_{k-1} \\
& \text { A adalah matriks keadaan }(\mathrm{n} \times \mathrm{n}) \\
& \text { B adalah matriks yang menghubungkan } \\
& A^{T} \quad \text { adalah matriks transpose A } \\
& P_{k}^{-} \quad \text { adalah kovarian kesalahan estimasi a } \\
& \text { priori saat } t_{k} \\
& P_{k-1} \quad \text { adalah kovarian kesalahan estimasi a } \\
& \text { posteriori saat } t_{k-1} \\
& \text { Q adalah kovarian noise }
\end{aligned}
$$

\section{Proses Koreksi}

Proses koreksi digunakan sebagai umpan balik. Persamaan matematisnya disebut persamaan measurement update. Pada proses koreksi ini yang pertama kali dihitung adalah Gain kalman, Perhitungan Gain kalman sebagai berikut[6]:

$$
K_{k}=P_{k}^{-} H^{T}\left(H P_{k}^{-} H^{T}+R\right)^{-1}
$$


Kemudian langkah selanjut adalah mendapatkan nilai estimasi a prioriori dengan rumus sebagai beriku[6]:

$$
\hat{x_{k}}=\hat{x_{k}^{-}}+K_{k}\left(z_{k}-H \hat{x_{k}^{-}}\right)
$$

Langkah terakhir menghitung kovarian kesalahan estimasi a posteriori adalah[6]:

$$
P_{k}=\left(I-K_{k} H\right) P_{k}^{-}
$$

Dimana:

$K_{k}$ adalah gain kalman

$P_{k}^{-}$adalah kovarian kesalahan estimasi a priori saat $t_{k}$

$\mathrm{R}$ adalah kovarian noise

$x_{k}$ adalah estimasi a posteriori saat $t_{k}$

$\wedge^{-}$

$\mathcal{X}_{k}$ adalah estimasi a priori saat $t_{k}$

$z_{k}$ adalah vector pengukuran saat $t_{k}$

$\mathrm{H}$ adalah

$H^{T}$ adalah matriks yang memberikan hubungan ideal antara pengukuran dan vector keadaan saat $t_{k}$

$P_{k}$ adalah kovarian kesalahan estimasi aposteriori saat $t_{k}$

I adalah matrik identitas

Proses diulang dengan perkiraan a posteriori sebelumnya yang digunakan untuk memproyeksikan atau memprediksi perkiraan a priori baru. Kalman filter bukan secara rekursif memproyeksikan perkiraan saat ini pada semua pengukuran sebelumnya.

Performa filter bergantung pada dua parameter ini yaitu parameter $\mathrm{Q}$ dan R. kovarian kesalahan estimasi $P_{k}$ dan Gain kalman $K_{k}$ akan distabilkan dengan cepat dan tetap konstan.

\section{Metode Penelitian}

Sistem yang dirancang terdiri dari tiga komponen utama yaitu komponen input, komponen pemprosesan dan komponen output seperti yang ditunjukkan pada Gambar 1.

Pada komponen input merupakan proses pengambilan video menggunakan ip camera atau web camera, hasil rekaman disimpan dalam sebuah drive penyimpanan pada komputer.

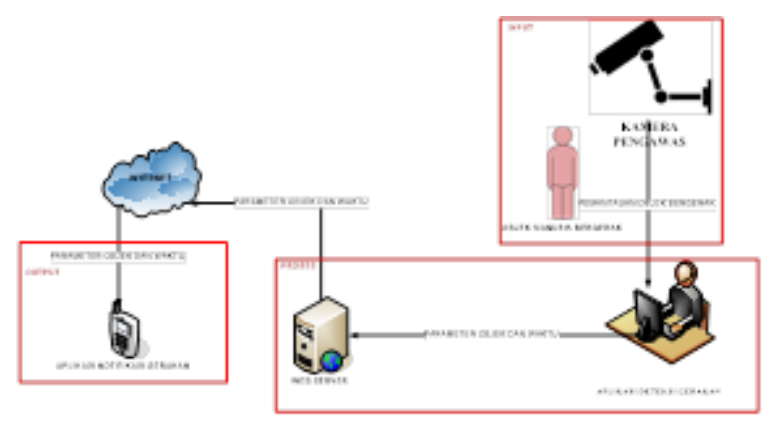

Gambar 1. Desain Arsitektur Sistem deteksi Gerakan

Untuk komponen pemprosesan terdiri dari system deteksi gerakan yang menerapkan metode kalman filter untuk memprediksi setiap gerakan yang terdeteksi dan segmentasi tresholding untuk mengsegmentasi gerakan yang terdeteksi. Pada proses penerapan metode kalman ada beberapa tahapan yang harus dilakukan diantaranya tahapan akuisisi objek video, inisialisasi dan membaca frame pada video, mendeteksi objek pada video, memprediksi lokasi baru pada alur frame pada video, menetapkan fungsi deteksi pada frame, memperbaharui informasi frame selanjutnya yang akan dideteksi, dan menampilkan hasil pelacakan. Pada tahapan akuisisi objek video digunakan untuk membaca tiap frame pada video yang kemudian mendeteksi objek( foreground) pada tiap frame dan menyimpannya kedalam data berupa array. Inisialisasi frame selanjutnya digunakan untuk membuat sebuah struktur yang mempresentasikan objek bergerak pada video. Tujuan dibuatnya struktur ini adalah untuk memonitor beberapa kondisi objek. Setelah tahapan inisialisasi frame dilakukan tahapan mendeteksi objek, dimana pada tahapan ini objek yang terdeteksi akan ditentukan titik centroid (titip pusat massanya) dan membuat masking berdasarkan hasil deteksi foreground untuk memvisualisasikan bounding box pada video. Kemudian dilakukan segmentasi gerakan menggunakan detector foreground, dimana segmentasi ini berisi operasi morfologi citra yang menghasilkan masking biner untuk menghilangkan noise dan mengisi lubang-lubang pada objek. Tahapan selanjutnya adalah memprediksi lokasi baru pada alur frame pada video, pada tahapan ini kalman filter digunakan untuk memprediksi centroid pada setiap frame dan mempernbaharui bounding box secara berkala. Tahapan menetapkan fungsi deteksi pada frame adalah menghitung nilai deteksi tiap frame menggunakan metode Euclidean distance antara centroid objek pada frame yang diprediksi dan centroid objek frame pada saat itu.pada proses ini juga dihitung nilai confidence pada frame yang diprediksi. Kedua 
nilai tersebut disimpan dalam matrik $\mathrm{m} \times \mathrm{n}$ dimana $\mathrm{m}$ adalah jumlah dari frame dan $\mathrm{n}$ adalah jumlah dariobjek yang dideteksi, matrik ini disebut cost matrix. Tahapan berikutnya adalah memperbaharui informasi frame selanjutnya yang akan dideteksi. Tahapan ini menggunakan metode korektor untuk mengkoreksi lokasi frame, kemudian memperbaharui bounding box dan menghitung total jumlah frame dan menghitung frame yang berisi objek. Tahapan terakhir adalah menampilkan objek hasil pelacakan pada bounding box dan memberikan label ID pada setiap objek bergerak pada video, kemudian menghasilkan deteksi foreground pada frame.

Dari hasil pemprosesan didapatkan parameter gerakan objek yang terdeteksi dan waktunya. Kedua parameter tersebut dari aplikasi deteksi gerakan disimpan dalam database pada web server. Parameter gerakan objek dan waktu pada database selanjutnya dikirimkan melalui jaringan internet. Informasi dari kedua parameter tersebut diterima oleh aplikasi notifikasi gerakan pada sisi android.

\section{Hasil Dan Pembahasan}

Hasil dari komponen pemrosesan yang telah dirancang untuk mendeteksi gerakan objek manusia menggunakan metode kalman filter seperti yang ditunjukkan pada Gambar 2.Pada Gambar 2 terlihat objek manusia berhasil dideteksi, kondisi ini ditandai dengan pemberian bounding box berwarna kuning dan label penomoran gerakan objek. Untuk mengantisipasi kondisi pada malam hari dimana pencahayaan disekitar lingkungan kamera kurang, aplikasi menyediakan fitur untuk mendeteksi gerakan objek dengan cara menampilkan frame video gerakan objek yang sudah tersegmentasi. Objek yang tersegmentasi (foreground) dibedakan dengan background, foreground berwarna putih sedangkan beckground berwarna hitam. Foreground yang tersegmentasi juga diberikan bounding box berwarna kuning dan label penomoran gerakan objek.



Gambar 2. Hasil implementasi komponen pemprosesan deteksi gerakan objek
Gerakan objek manusia yang terdeteksi oleh aplikasi diambil parameter gerakan dan waktunya untuk disimpan pada database mysql pada sisi web server seperti yang ditunjukkan pada Gambar 3. Data yang tersimpan untuk parameter gerakan disimpan dengan ID tertentu. Tiap ID menyimpan pergerakan yang terdeteksi mulai dari $1,101,201, \ldots$. dan seterusnya dimana tiap gerakan diberikan delay sebanyak 100 untuk mengantisipasi overload pengiriman data pada sisi web server.

Tampilan aplikasi notifikasi gerakan di sisi android seperti yang ditunjukkan pada Gambar 4. Setiap adanya deteksi gerakan yang tersimpan pada database maka web server akan meneruskan informasi parameter gerakan dan waktu melaului jaringan internet ke sisi android. Informasi tersebut akan diterima oleh aplikasi android berupa notifikasi adanya deteksi gerakan.

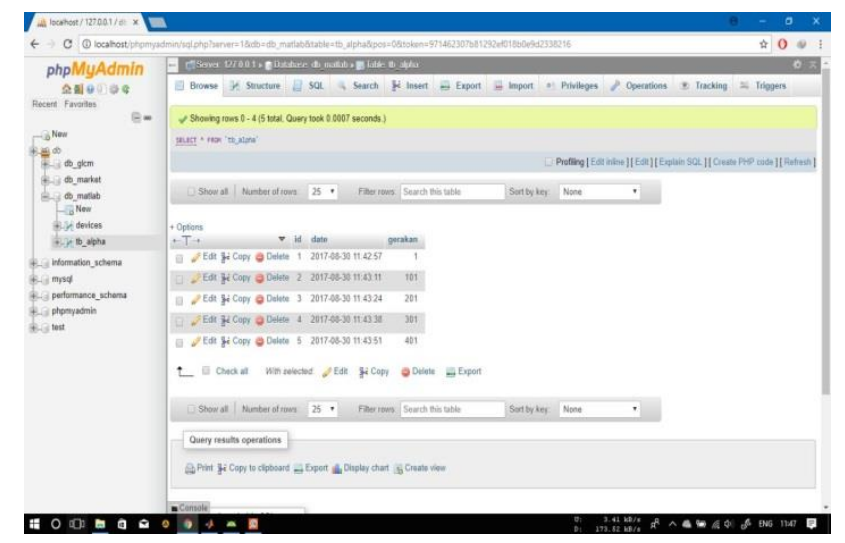

Gambar 3. Database mysql pada sisi web server

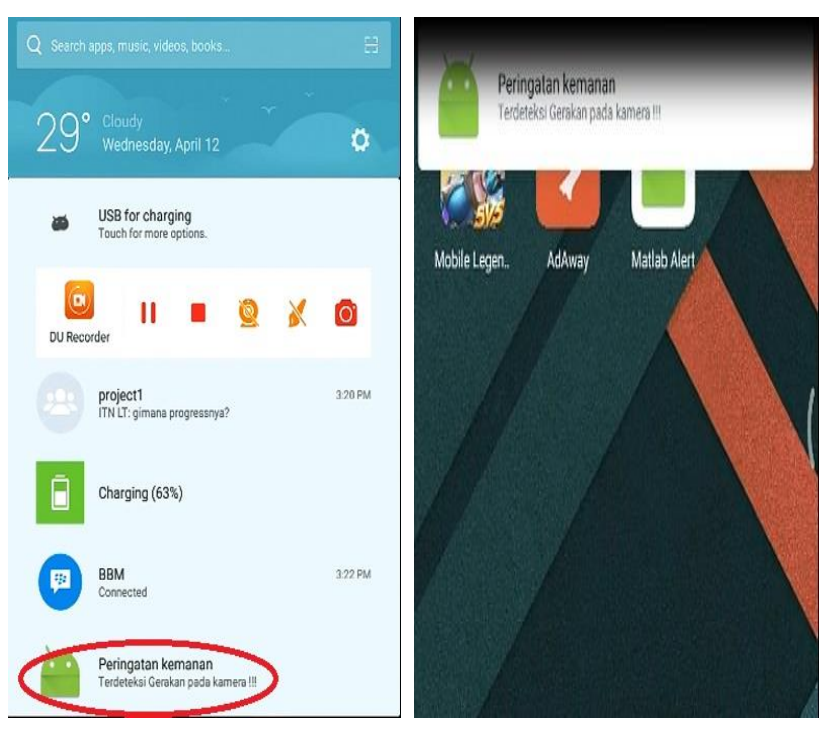

Gambar 4. Tampilan notifikasi di sisi android 


\section{- KESIMPULAN}

Dengan adanya aplikasi deteksi gerakan yang diterapkan pada kamera pengawas dapat membantu untuk memonitoring keamanan lingkungan sekitar. Aplikasi tersebut telah terbukti mampu mendeteksi objek manusia baik siang maupun malam hari. Setiap gerakan objek yang terdeteksi dapat disimpan dalam database pada sisi web server. Pengguna mendapatkan informasi deteksi gerakan objek manusia secara realtime melalui aplikasi android.

Untuk pengembangan aplikasi selanjutnya dapat menerapkan kamera CCTV karena sejauh ini masih menggunakan Ip Kamera yang mempengaruhi resolusi gambar video.Sejauh ini notifikasi masih pada sisi android pengguna, untuk pengembangan selanjutnya perlu ditambahkan fitur alarm apabila terdeteksi gerakan objek manusia pada malam hari.

\section{UCAPAN TERIMA KASIH}

Ucapan terima kasih biasanya diberikan pada Institut Teknologi nasional Malang yang telah mendanai Penelitian ini melalui Lembaga LPPM ITN Malang.

\section{DAFTAR Pustaka}

[1] Statistik Kriminal 2016 .Katalog BPS : 4401002.ISSN: 2089.5291. Nomor Publikasi : 04330.1601

[2] Diana.Lilis \& Mukhlish Amarullaah.2017.sistem deteksi objek bergerak dengan menggunakan teknik ROI dan algoritma Kalman filter.Jurnal masyarakat Informatika Indonesia.Vol 2.No.3 ISSN:2541

[3] Patel.Hitesh A \& Darshak G Thakore.2013.moving object tracking using kalman filter.international journal of computer science and mobile computing.Vol.2.ISSN: 2320088x.

[4] Jeong.Jong-Min,Tae-Sung Yoon \& Jin-Bae Park.2014.kalman filterbased multiple objects detectiontracking algorithm robust to occlusion.SICE Annual Conference 2014.September 9-12,2014,Hokkaido University,Sapporo,Japan

[5] Antonius.Alvin,Dedi Triyanto \& Ikhwan Ruslianto.2015.Penerapan pengolahan citra dengan metode adaptive motion detection algorithm pada system kamera keamanan dengan push notification ke smartphone android.Jurnal coding system computer untan.Vol.03,No.2.ISSN: 2338-493x

[6] Welch.Greg \& Gary Bishop.An Introduction To The Kalman Filter.University Of North Carolina At Chapel Hill Department Of Computer Science Chapel Hill, NC 27599. 3175.

[7] Gusa.Rika Favoria.2014.Teknik Rektifikasi Citra Dan Tapis Kalman Dalam Mengestimasi Kecepatan Kendaraan.Jurnal Nasional Teknik Elektro.Vol.3.No.1.ISSN: 2302-2949.

[8] Bakhtiar.2015.Kamera Pemantau Menggunakan Webcam.Jurnal SIGMATA.Vol.4.No.1.ISSN: 2302-5786.

[9] Umam.Faikul.2012.Estimasi Jarak Dan Posisi Orientasi Objek Menggunakan Stereo Kamera Dan Kalman Filter.SIMANTEC.Vol.3.No.1.ISSN: 2088-2130.

[10] Iswahyudi,Yuliman Purwanto, M.Arif Soleman,\& Ricardus Anggi Pramunendar.2013.Pelacakan kendaraan Bermotor Di Jalan Tol Semarang Menggunakan Kalman Filter Dan Mixture Of Gaussian Dengan Video Kualitas Rendah.Seminar Nasional Teknologi Informasi dan Komunikasi Terapan 2013.ISSN: 97926-0266-6. 
$\underline{\text { Teknologi Motion-Based Tracking Untuk Pengembangan Aplikasi Keamanan }}$ 